\title{
春䯣損傷透析患者の臨床的検討
}

\author{
伊藤恭彦 鈴木高志水野正司森田良樹 \\ 市田 静憲 宮川 幸一郎* 松 尾 清一* \\ 中部労災病院内科 名古屋大学第 3 内科*
}

key words : spinal cord injury, initiation of dialysis, creatinine, Pyelonephritis, FGS

〈要旨〉

脊髄損傷（脊損）患者にとって腎障害は致命的な合併症であり重要な問題のひとつである。今回，脊損腎不全患者 8 名における腎不全の特徵, 透析上の問題点を検討した。

透析導入までの期間は, 16.4 年であった。導入時平均クレアチニン值は $7.2 \pm 2.5 \mathrm{mg} / \mathrm{d} l$ と低值でありクレアチニ ンクリアランスとの解離を認める症例が存在し, 導入時期決定に注意を要する。導入時 $\mathrm{HCO}_{3}{ }^{-}$は平均 $10.9 \mathrm{mEq} / l$, $\mathrm{Na}$ は $122.1 \mathrm{mEq} / l$ と高度の体液異常を認めることが特徵である。導入理由として消化器症状が全例に，高度体液異 常を 5 例に，心不全を 3 例に認め，緊急導入となることが多い。導入前後を通じて裖創手術を 5 名が経験しており， 3 例は菌血症に陥っている。導入期に肺炎を 2 名が併発しており尿路感染症とともに感染症対策が重要である。導入 期は，体液異常, 感染症, 栄養不良等の理由から死亡率が高く導入期はより慎重な対応が必要となる。VUR は 2 例 3 腎に見るのみであったが, 水腎は 6 例 11 腎に認めた。神経因性膀胱による尿路障害とこれに伴う尿路感染症が脊髄損 傷, 慢性腎不全の原因・増悪因子となるが，全例に蛋白尿を認め系球体障害の合併が疑われ，剖検例ではVUR の有 無にかかわらず巣状糸球体硬化病変を認めた。

春髄損傷腎不全患者は特異な疾患群といえこれらの特徵を認識して対応する必要がある。

\section{Clinical features of chronic renal failure associated with spinal cord injury}

Yasuhiko Ito, Takashi Suzuki, Masashi Mizuno, Yoshiki Morita, Shizunori Ichida, Kouichirou Miyakawa*, Seiichi Matsuo*

Department of Internal Medicine, Chubu Rousai Hospital ; Third Department of Internal Medicine, Nagoya University School of Medicine*

The characteristics of end-stage renal disease associated with spinal cord injury were studied in 8 hemodialysis patients. The mean interval between the onset of spinal cord injury $(\mathrm{SCl})$ and the institution of maintenance hemodialysis was 16.4 years. At the time of initiation of hemodialysis, the mean serum creatinine concentration was $7.2 \pm 2.5 \mathrm{mg} / \mathrm{d} l$ and was markedly lower than that of the glomerulonephritic group. Mean bicarbonate was $10.9 \mathrm{mEq} / l$, and mean $\mathrm{Na}$ was $122.1 \mathrm{mEq} / l$. The main causes of the initiation of hemodialysis were fluid and electrolyte abnormalities, gastro-intestinal symptoms and heart failure. In many cases, emergency hemodialysis therapy was required. Two cases suffered from pneumonia. Surgical treatment for decubiti was undertaken in five cases, three of whom suffered from septicemia. Thus, more effective prevention and control of infections, nutrition and electrolyte balance would result in reduced morbidity and mortality rates in $\mathrm{SCl}$ patients. Vesicoureteral reflux (VUR) was found only in 3 kidney.s of 2 cases, but hydronephrosis was present in 11 kidneys of 6 cases. Urinary tract infections associated with neurogenic bladder were the major cause of chronic renal failure in $\mathrm{SCI}$ patients. All SCl patients exhibited moderate to marked proteinuria, and glomerular abnormalities existed under these conditions. In conclusion, chronic renal failure complicating the course of long standing spinal cord injury represents a unique clinical condition.

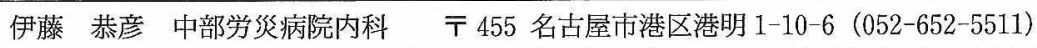

〔受付: 平成 5 年 4 月 16 日, 受理: 平成 5 年 9 月 6 日〕 
表 1 脊髄損傷血液透析患者例

\begin{tabular}{|c|c|c|c|c|c|c|c|c|}
\hline 症例 & 性 & $\begin{array}{l}\text { 透析導入時 } \\
\text { 年齢 (歳) }\end{array}$ & $\begin{array}{l}\text { 損傷 } \\
\text { 部位 } \\
\end{array}$ & 原因 & $\begin{array}{l}\mathrm{HD} \text { 導入までの } \\
\text { 期間 (年) }\end{array}$ & $\begin{array}{l}\text { 䙏創 } \\
\text { 手術 }\end{array}$ & その他の身体の状況 & 転 㷌 \\
\hline 1. & 男 & 51 & $\mathrm{~L}_{2}$ & 労災 & 18 & 3 回 & 慢性膵炎（アルコール性） & 維持透析中. \\
\hline 2 & 女 & 64 & $\mathrm{Th}_{12}$ & 交通事故 & 27 & 1 回 & & $\begin{array}{l}\text { 死亡 (導入 } 1 \text { か月後, } \\
\text { uremic encephalopathy) }\end{array}$ \\
\hline 3 & 男 & 32 & $\mathrm{Th}_{5}$ & 交通事故 & 14 & 3 回 & & 維持透析中 \\
\hline 4 & 男 & 41 & $\mathrm{Th}_{12}$ & 労災 & 21 & 4 回 & & 維持透析中 \\
\hline 5 & 男 & 67 & $\mathrm{C}_{6}$ & $\begin{array}{l}\text { 自宅 } 2 \text { 階 } \\
\text { より転落 }\end{array}$ & 3 & $(-)$ & & 維持透析中 \\
\hline 6 & 男 & 63 & $\mathrm{Th}_{11}$ & 労災 & 20 & 2 回 & & $\begin{array}{l}\text { 死亡（導入 } 1 \text { 加以以内, } \\
\text { 肺炎, ARDS) }\end{array}$ \\
\hline 7 & 男 & 38 & $\mathrm{Th}_{11}$ & 労災 & 16 & $(-)$ & $\begin{array}{l}\text { 左腎摘出状態 } \\
\text { 人工肛門, HB キャリヤー }\end{array}$ & $\begin{array}{l}\text { 死亡 (導入 } 3 \text { か月後, } \\
\text { 脳出血) }\end{array}$ \\
\hline 8 & 女 & 38 & $\mathrm{~L}_{2}$ & 労災 & 12 & $(-)$ & & 維持透析中 \\
\hline
\end{tabular}

\section{緒言}

脊髄損傷患者に対する尿路管理方法の進歩に伴い腎不 全に宿る症例は減少傾向にあるが，腎障害は致命的な合 併症であり依然重要な問題のひとつといえる. 1953 年か ら 1982 年の 30 年間, 全国労災病院における春髅損傷死 亡患者 790 名のうち, 感染を含めた腎障害による死亡者 が $28 \%$ と第 1 位を占めている事実はこの問題の重要性 を示唆している ${ }^{1,2)}$. かつ，末期腎不全で血液透析に導入 されてもその生命予後は不良と報告されている ${ }^{3)}$. 近年, 血液透析療法の進歩に伴い, 糖尿病性腎症をはじめ多彩 な合併症をもつ患者群の予後の改善が報告されている が4), 国内における脊髄損傷慢性腎不全患者の治療に関 する検討は少ない。今回, 我々は脊髄損傷患者で維持透 析に至った患者の腎不全の特徴，診断および治療上の問 題点を検討した.

\section{対象と方法}

対象は, 昭和 60 年 1 月から平成 3 年 12 月までに中部 労災病院で血液透析に導入された脊䯣損傷を伴う慢性腎 不全患者 8 名, うち男性 6 , 女性 2 名で, 年齢は $32 \sim 67$ 歳, 平均 $49.3 \pm 13.9$ 歳であった. 血液透析導入前の尿路 管理法，腎不全背景因子・増悪因子，導入期の特徵・問 題点，また剖検例につき組織学的検討を行った。 なお, 『腎機能低下時期』は，血清クレアチニン值 $(\mathrm{Cr})$ が 1.5 $\mathrm{mg} / \mathrm{d} l$ 以上となった時点とした.

\section{結果}

表 1 のごとく患者群の脊䯣損傷部位は, 頸䯣 1 名, 胸 髄 5 名, 腰髄 2 名であり, 原因は労働災害 5 名, 交通事 故 2 名， 2 階からの転落事故が 1 名であった．脊䯣損傷 より透析導入までの期間は平均 16.4 年であった。導入前 後を通じ，褯創手術を 5 名が経験しておう，4 例は複数 回の裖創手術を受けていた。また，このうち 3 例が裖創
表 2 血液透析導入前の尿路管理法

\begin{tabular}{|c|c|c|c|c|c|}
\hline & \multirow{2}{*}{ 固定期尿路管理法 } & \multicolumn{2}{|c|}{ 水 腎 } & \multicolumn{2}{|c|}{ VUR } \\
\hline & & $\mathrm{rt}$ & It & $\mathrm{rt}$ & lt \\
\hline 1 & 腹圧 - 手圧 $\cdot$ 排尿 & $(-)$ & $(-)$ & $(-)$ & $(-)$ \\
\hline 2 & 膀胱瘦（受傷 22 年） & $(+)$ & $(+)$ & III & $(-)$ \\
\hline 3 & $\begin{array}{l}\text { 括約筋切開術 } \\
\text { 膀腃瘻（受傷 } 10 \text { 年) }\end{array}$ & $(+)$ & $(+)$ & $(-)$ & $(-)$ \\
\hline 4 & 無菌的間歇導泳法 & $(+)$ & $(+)$ & $(-)$ & $(-)$ \\
\hline 5 & $\begin{array}{l}\text { 括約筋切開術（受傷 } 2 \text { 年） } \\
\text { 無菌的間歇導泳法 }\end{array}$ & $(-)$ & $(-)$ & $(-)$ & $(-)$ \\
\hline 6 & $\begin{array}{l}\text { 括約筋切開術（受傷 } 13 \text { 年） } \\
\text { 無菌的間歇導湶法 }\end{array}$ & $(+)$ & $(+)$ & $(-)$ & $(-)$ \\
\hline 7 & 右尿管皮膚瘻（受傷 13 年） & $(+)$ & 腎摘後 & $(-)$ & 腎摘後 \\
\hline 8 & 回腸導管（受傷 12 年） & $(+)$ & $(+)$ & II & III \\
\hline
\end{tabular}

が原因で導入後に菌血症に宿っている，その他の身体状 況として症例 7 は労災損傷による左腎摘出, 人工肛門状 態であった。転帰は, 症例 $2,6,7$ と 3 例が死亡し, それぞれ導入 1 か月，20日，3加月後と全例導入早期の 死亡であったことは注目された。他の 5 例は, 現在全例 外来維持透析中である.

血液透析導入前の尿路管理法(表 2)：無菌的間歇導尿 3 例, 膀胧㾞 2 例, 尿管皮膚癭 1 例, 回腸導管 1 例で, 3 例に括約筋切開術が施行されている. 膀胱尿管逆流現 象 (VUR) は2 例，3腎に見られたのみであったが，水 腎は 6 例, 11 腎に認められた。症例 1 は, VUR・水腎と もに認められず用手管理による排尿形式であった。

腎機能低下に関する検討（表 3 ）：腎機能低下時期は， 1 から 17 年, 平均 11 年であったのに対し, このレベル から透析導入までの期間は 2 から 11 年, 平均 5.6 年と短 期間であった。蛋白尿は，全例に認められ， 5 例が $3 \mathrm{~g} /$ 
表 3 腎機能低下に関守る検討

\begin{tabular}{|c|c|c|c|c|c|c|c|c|}
\hline \multirow{2}{*}{ 症例 } & \multirow{2}{*}{$\begin{array}{l}\text { 腎機能 } \\
\text { 低下時期 }\end{array}$} & \multirow{2}{*}{$\begin{array}{l}\text { 腎機能低下から } \\
\text { 導入までの期間 }\end{array}$} & \multirow{2}{*}{$\begin{array}{c}\text { 蛋白尿 } \\
\text { (g/day) }\end{array}$} & \multicolumn{4}{|c|}{ 腎機能低下因子 } & \multirow{2}{*}{ 尿細菌 } \\
\hline & & & & UTI & 水腎 & VUR & $\mathrm{HT}$ & \\
\hline 1 & 15 年 & 3 年 & $2 \sim 4$ & $(+)$ & $(-)$ & $(-)$ & $(+)$ & Ent. faecium \\
\hline 2 & 16 年 & 11 年 & $1 \sim 2$ & $(+)$ & $(+)$ & $(+)$ & $(-)$ & C. freundii \\
\hline 3 & 9 年 & 5 年 & $3 \sim 5$ & $(+)$ & $(t)$ & $(-)$ & $(+)$ & $\begin{array}{l}\text { M. morganii } \\
\text { Pseudo. aeruginosa }\end{array}$ \\
\hline 4 & 17 年 & 4 年 & 3 & $(+)$ & $(+)$ & $(-)$ & $(+)$ & Pseudo. aeruginosa \\
\hline 5 & 1 年 & 2 年 & 3 & $(H)$ & $(-)$ & $(-)$ & $(-)$ & MRSA \\
\hline 6 & 13 年 & 7 年 & 3 & $(+)$ & $(+)$ & $(-)$ & $(-)$ & $\begin{array}{l}\text { Achromobacter } \\
\text { xylosoxydans }\end{array}$ \\
\hline 7 & 12 年 & 6 年 & $0.5 \sim 1.0$ & $(+)$ & $(+)$ & $(-)$ & $(+)$ & Pseudo. maltophilia \\
\hline 8 & 5 年 & 7 年 & 1 & $(+)$ & $(+)$ & $(+)$ & $(+)$ & $\begin{array}{l}\text { E. coli } \\
\text { Acinetobacter }\end{array}$ \\
\hline
\end{tabular}

表 4 血液透析導入時状況

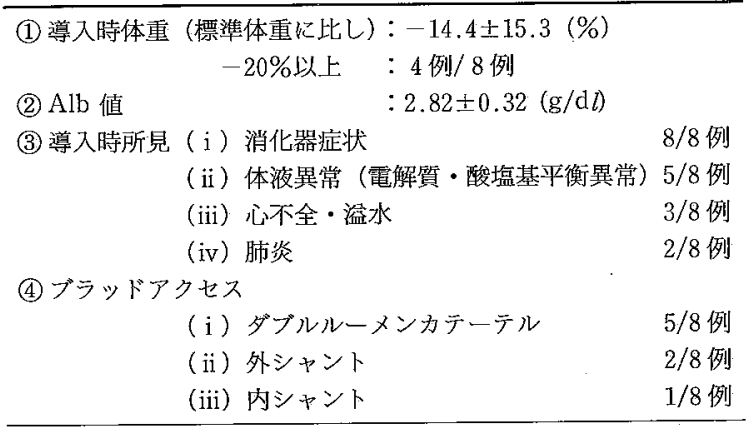

day 以上と，系球体障害の合併が示唆された，腎機能低 下因子として全例に経過中の繰り返す尿路感染症をみ, 弱毒菌がその主体を占めた. 水腎, VUR と尿流障害の関 与が高率に見られたが，それらがともに存在しない症例 1 は慢性腎炎の存在が疑われ, 症例 5 は脊損の入院時す でに尿蛋白が陽性，クレアチニン $1.4 \mathrm{mg} / \mathrm{d} l$ と慢性の腎 障害が存在し，その上に急性腎盂腎炎を繰り返し，さら に薬剤の影響も加わり末期腎不全に至ったと考えられ た。また高血圧は 5 例に認められた。

血液透析導入時状況（表 4 ）：導入時の身長・体重は, 症例 $1: 153 \mathrm{~cm}, 44 \mathrm{~kg}$. 症例 $2: 150 \mathrm{~cm}, 43 \mathrm{~kg}$. 症例 $3: 173 \mathrm{~cm}, 50 \mathrm{~kg}$. 症例 $4: 166 \mathrm{~cm}, 48 \mathrm{~kg}$. 症例 $5: 165$ $\mathrm{cm}, 50 \mathrm{~kg}$. 症例 $6: 162 \mathrm{~cm}, 42 \mathrm{~kg}$. 症例 $7: 163 \mathrm{~cm}, 40$ $\mathrm{kg}$. 症例 $8: 160 \mathrm{~cm}, 63 \mathrm{~kg}$ であった. 体重のみならず血 清アルブミン值 (Alb) も低值を示し, 筋萎縮のみならず 栄養不良の存在が示唆された。 導入理由として消化器症 状が全例に，体液異常（代謝性アシドーシス，低 $\mathrm{Na}$ 血 症）を 5 例，心不全を 3 例に認めた。また，導入時 2 例 が肺炎を併発している.ブラッドアクセスはダブルルー
血液透析導入時検査所見 (I)

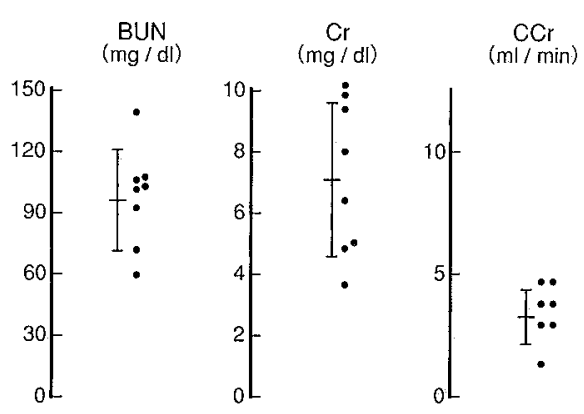

血液透析導入時検查所見（II）

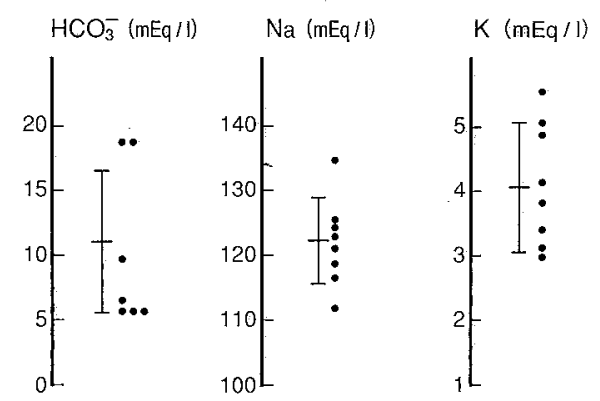

図 1 血液透析導入時検查所見

メンカテーテル，外シャントが中心であった。

導入時検査所見 (図 1) : BUN は平均 $96.7 \pm 23.5 \mathrm{mg} /$ $\mathrm{d} l$ と高值であるのに対し $\mathrm{Cr}$ は $7.2 \pm 2.5 \mathrm{mg} / \mathrm{d} l$ と低值を 示した. 一方クレアチニンクリアランス (CCr) は, $3.4 \pm$ $1.1 \mathrm{~m} l /$ 分と高度低下を示した. $\mathrm{HCO}_{3}{ }^{-}$は平均 10.9 $\mathrm{mEq} / l, \mathrm{Na}$ は, 平均 $122.1 \mathrm{mEq} / l$ と, 高度の代謝性ア シドーシス, 低 $\mathrm{Na}$ 血症を呈した。 
症例 2 を提示する (図 2 )。6 5 歳女性で，昭和 39 年交 通事故による胸䯣損傷。昭和 61 年膀胱湄造設。Cr は， 昭和 63 年 $2.7 \mathrm{mg} / \mathrm{d} l$, 平成 3 年 2 月 $2.8 \mathrm{mg} / \mathrm{d} l$ であった。 同年 4 月より発熱，食欲低下出現し 5 月 2 日緊急入院と なる。Cr $5.4 \mathrm{mg} / \mathrm{d} l, \mathrm{BUN} 109 \mathrm{mg} / \mathrm{d} l, \mathrm{HCO}_{3}{ }^{-} 6 \mathrm{mEq} / l$ と急性増覀を示したため血液透析を施行。2 回の HDで 離脱したが，腎盂腎炎によると思われる発熱が持続し， 種々の抗菌剤の使用が余儀なくされた。6月から 10 月ま で BUN は 60 から $100 \mathrm{mg} / \mathrm{d} l$ と高值を示したが $\mathrm{Cr}$ は 3 から $4 \mathrm{mg} / \mathrm{d} l$ 程度であった。CCr は徐々に低下し， $\beta_{2}$ microglobulin $\left(\beta_{2}-\mathrm{MG}\right)$ の上昇も続き11月 14 日 BUN $70 \mathrm{mg} / \mathrm{d} l$, Cr $3.7 \mathrm{mg} / \mathrm{d} l$, CCr $4 l /$ day, $\beta_{2}-\mathrm{MG} 42.8 \mathrm{mg} / l$ で透析導入となった。週 3 回 3 時間の透析を行ったが， データ不変のため週 2 回 3.5 時間へ短縮したところ 1 週 間後に意識障害，不随運動，皮膚症状悪化等が出現した。 脳波は広範な徐波を認めたが，頭部 CT, MRI 上異常は なかった。意識障害，血圧下降をきたし透析不能状態に 陥り1週問で死亡した。臨床および剖検所見より尿毒症 性脳症 (uremic encephalopathy) が疑われた。本例は著 明な $\mathrm{CCr}$ 低下， $\beta_{2}-\mathrm{MG}$ の上昇を認めたが，Cr 值の上 昇は軽度であり導入の時期決定が難しかった 1 例であっ
た。

剖検腎の検討（図 3）：A は症例 2 の腎の断面を示す が，慢性㹂盂腎炎が主体の高度萎縮腎であった。B は症 例 2 の右腎，C は症例 2 の左腎，D は症例 6 の右腎であ るが, 各々巣状硬化病変を認めた。さらに症例 6 左腎も 同様に巣状硬化病変を見たが，VUR は症例 2 の右腎に 確認するのみであった。

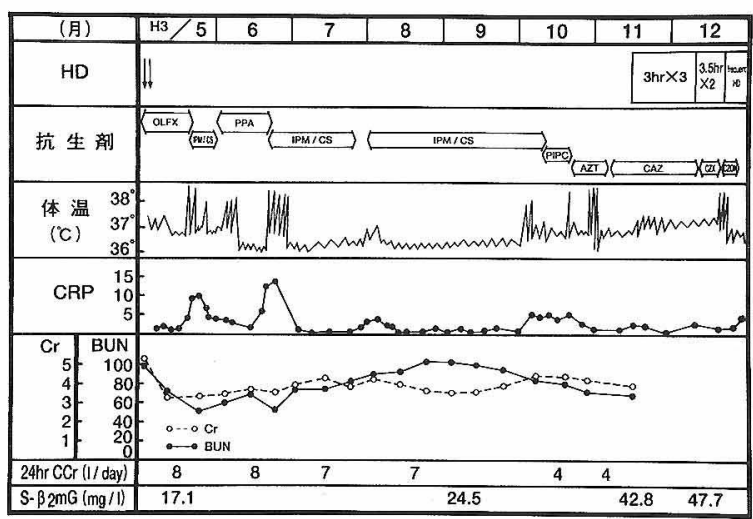

図 2 症例 2 の臨床経過
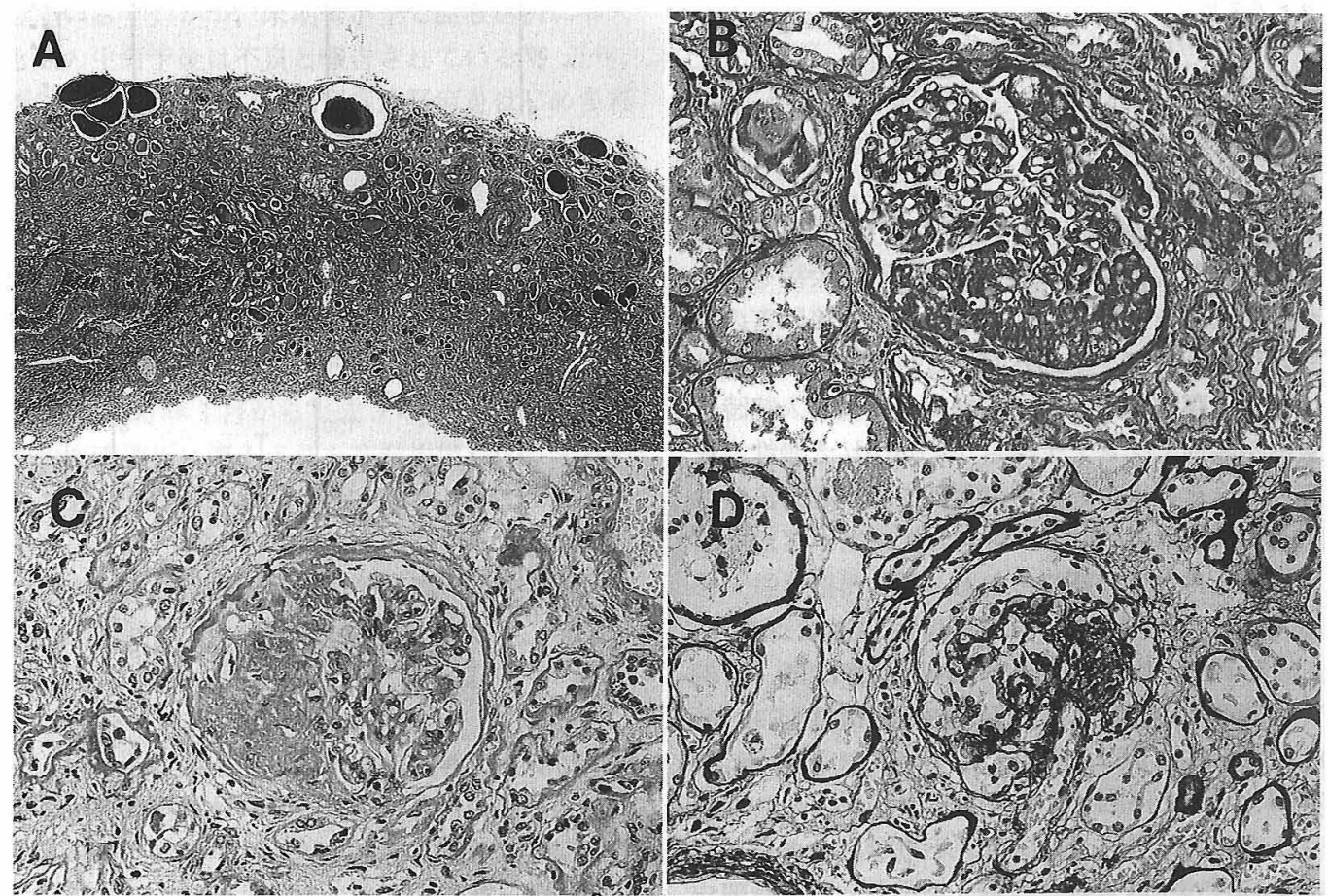

図 $3 \mathrm{~A}$ ：症例 2。腎孟腎炎主体の高度萎縮腎所見を見る (AZAN 染色)。B： 症例 2。右腎 FGS 病変を認める (AZAN 染色)。C：症例 2 。左腎 FGS 病変を認める (PAS 染伋). D : 症例 6 . 右腎 FGS 病変を認める (PAM 染色). 


\section{考案}

脊髄損傷患者の腎不全を急性, 慢性と分けると前者は 損傷に伴う横紋筋融解, ショックが主な原因となる. 後 者は今回の検討からもわかるように神経因性膀胱による 尿路通過障害とこれに伴う尿路感染症が主因となり，こ れに原発性腎障害, 高血压, 薬剤等が複雑に関与してい ると考えられる。脊髄損傷患者の Amyloidosis は海外に おいては報告が多いが5), 本邦では稀とされ, 我々の症例 でも見られていない.

春䯣損傷慢性腎不全の特幑の一つは, Vaziri らも警告 を与えているように ${ }^{6,7)}$, 他の原因の腎不全患者と比較し て導入時の $\mathrm{Cr}$ 低值例が多く, $\mathrm{CCr}$ との解離を認め, 導 入期の評価に注意を要することである。血清 $\mathrm{Cr}$ 值が $\mathrm{CCr}$ に比し低值であるのは，脊損による筋萎縮のため内 因性クレアチニンの産生量が減少しているためと考えら れた。また， Cr 1台から導入までの期間が平均 5.6 年 と極めて短いことも Cr 值と実際の腎機能との解離が一 つの要因と思われた。さらに，本患者群は，抗生物質を はじめ種々の薬剤を使用する機会が多いが，保存期にお いて正確に腎機能を把握することは副作用を回避する上 でも重要と思われた。

第二の特徵として低 $\mathrm{Na}$ 血症, 代謝性アシドーシス等 高度の体液異常を是する症例が多く, 緊急導入の原因と なりうる点が挙げられる。これは，基礎疾患である慢性 腎血腎炎による腎間質障害が高度である点，閉塞性腎症 (obstructive nephropathy) による酸排泄障害の影響等 が関与していると思われた ${ }^{8)}$.また, 導入時のブラッドア クセスがダブルルーメンカテーテル，外シャント中心で あったのは，緊急導入が多かったことと，血管荒廃によ る内シャント作成が困難のためであった。

第三に，本患者群は感染症の合併頻度が高率なことで ある、腎盂腎炎を中心とした尿路感染症はほほ必発であ るが, 重症化すると腎内・腎周囲腫瘍 (intra/perinephric abscess) を形成するに至るものもあると述べられてい る ${ }^{5)}$. 呼吸器感染症も高頻度であり ${ }^{9)}$, 我々が経験した導 入期に合併した肺炎は，治療上重大な問題であった。裖 創は脊䯣損傷患者の $71 \%$ に及ぶといわれ ${ }^{10)}$, 今回検討し た患者群においても半数例に複数回の裖創手術が行わ れ，かつ 3 例は菌血症に至っている。これは導入期のみ ならず維持透析期においても重要な問題となる。さらに, これら尿路・呼吸器・裖創感染はシャント感染への感染 源となりうるとの報告も見られている ${ }^{11)}$.これら感染症 は栄養状熊, 貧血等にも関与し長期予後にも影響を与え る重要な因子と考える。

導入後の予後は一般的に不良とされ，海外では 1 年生 存率 $60 \%, 2$ 年生存率 $50 \%$ といわれる ${ }^{12)}$. 我々の検討で
は導入早期の死亡率が高く，これらは緊急導入に至る代 謝性アシドーシス，低 $\mathrm{Na}$ 血症を中心とする高度体液異 常のみならず，栄養障害，感染症等の全身状態の悪化が 関与していた.よって導入期の全身管理にはより慎重な 対応が必要となる。

さて，今回の腎機能低下に関する検討の中で興味深 かったことは，ほぼ全例が $1 \mathrm{~g} /$ 日以上の蛋白尿を呈し糸 球体障害の合併が示唆されたことである。これらの症例 中 2 例に前述のごとく既存の腎障害，原発性腎炎の合併 と思われる症例があったが，他は臨床経過より慢性腎需 腎炎が主な病因と思われた。経験しえた 2 剖検例は明ら かな慢性腎孟腎炎の病理組織像を呈したが 4 腎すべてに 巣状系球体硬化所見 (FGS) を認め，この病変が蛋白尿 および糸球体硬化進展に関与している可能性が考えられ た. VUR が巣状糸球体硬化症を惹起することは有名て あるが ${ }^{13)}$ ，我々が経験した FGS を認めた剖検 2 例，4 腎のうち 1 腎のみしか.VUR は確認できなかった. 近年, 尿細管・間質障害に伴う細胞から放出されるサイトカイ ンが糸球体硬化の誘因, 促進因子となることが報告され ている ${ }^{14,15)}$.また，尿細管・間質障害に伴う atubular glomeruli ${ }^{16,17)}$ による腎機能低下という概念も提唱され さらにこの機序によって FGS 病変が生ずることも推測 されている ${ }^{17)}$. 間質障害からの糸球体障害・硬化進展がこ れら脊䯣損傷患者の慢性腎盂腎炎から腎不全に至る重要 な因子となっている可能性が考えられ興味ある所見と思 われた。

\section{結論}

1. 神経因性膀胱による尿路障害とこれに伴う尿路感 染症が脊髄損傷患者慢性腎不全の主因となる。

2. 導入時クレアチニン值は低值例が多く，クレアチ ニンクリアランスとの解離を認める症例が存在する。透 析導入の腎機能の指標として血清クレアチニン值のみの 評価では不十分であり CCr の検討が重要となる.

3．強度の代謝性アシドーシス，低 $\mathrm{Na}$ 血症を呈する 症例が多い.

4. 基礎疾患として全例に腎跙腎炎が存在し, 腎不全 進展に間質障害のみならず糸球体障害の合併が示唆され た.

5. 尿路感染症のみならず裖創・呼吸器感染を含めた 感染症対策が重要となる.

6. 導入早期の死亡率が高く, 導入期は慎重な対応が 重要である。

7. 以上より脊髄損傷腎不全患者は特異な患者群とい え, これらの特徵を認識して対応する必要がある。

本論文の要旨は第 37 回日本透析療法学会総会 (横浜) にて 
発表した.

\section{文献}

1）鈴木勝己，本田純男：労災病院における脊髄損傷患 者死因統計。日災害医誌 $17 ： 124-132,1969$

2) 本田純男：労災病院における脊髅損傷患者死因統計 (続報)。日災害医誌 $32 ： 302-309 ， 1984$

3) Stacy WK, Falls WF, Hussey RW : Chronic hemodialysis of spinal cord injury patients. J Am Paraplegia Soc 6:7-9, 1983

4）柴田昌雄, 大沢源吾 (座長)：糖尿病性腎症の維持透 析. 透析会誌 $24: 1610-1637,1991$

5) Barton $\mathrm{CH}$, Vaziriz ND, Gordon S, Tilles S: Renal pathology in end stage renal disease associated with paraplegia. Paraplegia $22: 31-41$, 1984

6) Vaziri ND, Bruno A, Mirahmadi MK, Golgi $\mathrm{H}$, Gordon S, Byrne C: Features of residual renal function in end-stage renal failure associated with spinal cord injury. Artif Organs 7 : 319-322, 1984

7) Mirahmadi MK, Byrne C, Barton C, Penera N, Gordon S, Vaziri ND : Prediction of creatinine clearance from serum creatinine in spinal cord injury patients. Paraplegia 21:23-29, 1983

8) Yarger WE : Urinary tract obstruction. In "The Kidney, Vol 2, No. 1", ed Brenner BM, Rector FC, p 1768-1808, Saunders, Philadelphia, 1991

9) Fairshter RD, Vaziri ND, Gordon S : Frequency and spectrum of pulmonary diseases in patients with chronic renal failure associated with spinal cord injury. Respiration 44 : 58-62, 1983

10) Nakajima A, Honda S : Physical and social condition of rehabilitated spinal cord injury patients in Japan: A long-term review. Paraplegia 26 : $165-176,1988$

11) Vaziri ND, Cesario $T$, Mootoo $K$, Gordon $S$, Byrne $\mathrm{C}$ : Bacterial infections in patients with chronic renal failure. Occurrence with spinal cord injury. Arch Intern Med 142 : 1273-1276, 1982

12) Mirahmadi MK, Vaziri ND, Ghobadi M, Nikakh$\operatorname{tar}$ B, Gordon S: Survival on maintenance dialysis in patients with chronic renal failure associated with paraplegia and quadriplegia. Paraplegia $20: 43-47,1982$

13) Zucchelli P, Gaggi R : Reflux nephropathy in adults. Nephron $57: 2-9,1991$

14) Remuzzi $G$, Bertani $T$ : Is glomerulosclerosis a consequence of altered glomerular permeability to macromolecules. Kidney Int $38: 384-394,1990$

15) Nath KA : Tubulointerstitial changes as a major determinant in the progression of renal damage. Am J Kidney Dis 20:1-17, 1992

16) Marcussen $\mathrm{N}$, Olsen TS : Atubular glomeruli in patients with chronic pyelonephritis. Lab Invest $62: 467-473,1990$

17) Marcussen $\mathrm{N}$ : Atubular glomeruli and the structural basis for chronic renal failure. Lab Invest $66: 265-284,1992$ 